\title{
Monogonot rotifers species of the island Cozumel, Quintana Roo, México
}

Jovana Lizeth Arroyo-Castro ${ }^{\ddagger}$, Jesús Alvarado-Flores ${ }^{\ddagger}$, Juan Carlos Uh-Moo ${ }^{\S}$, Coral Grisel KohPasosl

‡ Centro de Investigación Científica de Yucatán A.C., Benito Juárez, Cancún, Mexico

$\S$ Manejo de Recursos Naturales Isla Cozumel A.C., Cozumel, Mexico

| Ecología de Carreteras, Cozumel, Quintana Roo, Mexico

Corresponding author: Jesús Alvarado-Flores (jesus.alvarado@cicy.mx)

Academic editor: Christos Arvanitidis

Received: 21 Mar 2019 | Accepted: 06 Jun 2019 | Published: 13 Jun 2019

Citation: Arroyo-Castro J, Alvarado-Flores J, Uh-Moo J, Koh-Pasos C (2019) Monogonot rotifers species of the island Cozumel, Quintana Roo, México. Biodiversity Data Journal 7: e34719. https://doi.org/10.3897/BDJ.7.e34719

\section{Abstract}

The current study adds 23 new records to the previously described monogonot rotifers of Cozumel, increasing the number of reported species to 40; these species are grouped into two orders, 11 families and 18 genera. Littoral and limnetic samples from 17 aquatic systems were examined, including wet dolines, coastal lagoons, temporary pools and artificial systems (reservoirs). Of the 36 species found, the following organisms represent new findings for Cozumel: Anuraeopsis fissa, Brachionus angularis, B. rubens, B. plicatilis sensu lato, Beuchampiella eudactylota, Euchlanis dilatata, Mytilina bisulcata, Colurella adriatica, Lepadella ovalis, L. rhomboides, Squatinella mutica, Lecane aculeata, L. climacois, L. crepida, L. cornuta, L. grandis, L. obtusa, L. pyriformis, Cephalodella forficula, Scaridium bostjani, Trichocerca pusilla, Polyarthra cf. dolichoptera, P. vulgaris, Dicranophorus epicharis and Testudinella patina. Additional information is reported for these species.

\section{Keywords}

Caribbean Sea, zooplankton, island systems, diversity 


\section{Introduction}

Islands contain ecosystems of critical importance for biodiversity conservation since a large number of endemic species are distributed in these environments. Furthermore, islands are important sites for the reproductive, nesting, resting and feeding activities of numerous species, including migratory species (Salazar-Vallejo and González 1993). Despite their great importance, current knowledge about the biodiversity of Mexican islands is limited (Lara-Lara et al. 2008). A Mexican Institute CONABIO-CONANP-TNC-PRONATURA (2007) mentioned that Mexico's island diversity has not been studied as extensively as terrestrial diversity.

In these ways, several studies on the different taxonomical groups, associated with 149 Mexican islands, have been carried out, in which 2,545 marine species and 2,066 terrestrial species, grouped into 1,830 genera and 655 families, have been reported (CONABIO-CONANP-TNC-PRONATURA 2007). The groups that are studied mostly include birds, algae, fish, reptiles and angiosperms. However, microorganism groups, such as zooplankton and, in particular, rotifers, are not included in these lists even though efforts to understand and increase knowledge about rotifers have intensified in the past two decades. For instance, one inventory of approximately 300 specific rotifer forms (mainly found in fresh water) was created by Elías-Gutiérrez and García-Morales (2011).

Studies have been elaborated mainly for Mexico's central region, including inventories by Rico-Martínez and Silva-Briano (1993), Sarma et al. (1996), Serranía-Soto (1996), Sarma and Elías-Gutiérrez (1997), Sarma and Elías-Gutiérrez (1998), Sarma and Elías-Gutiérrez (1999) and its south-eastern region (Chiapas, Tabasco, Yucatan and Quintana Roo) in the works of Sarma et al. (2000), Schmitter-Soto et al. (2002), García-Morales and ElíasGutiérrez (2004), Cervantes-Martínez (2005), García-Morales and Elías-Gutiérrez (2007), Benítez-Díaz et al. (2014). Until now, these studies have focused on continental aquatic systems, leaving behind the advancement of knowledge of this group in island systems. In Mexico, the total area of island systems is $5,083 \mathrm{~km}^{2}$ (including small islands, islets, keys and rocks). Cozumel is the third largest island in Mexico $\left(477 \mathrm{~km}^{2}\right)$, following the islands of Tiburón and Ángel de la Guarda (Aguirre-Muñoz et al. 2010). In Cozumel, a total of 533 species have been recorded and are distributed between two main groups: aquatic and terrestrial organisms. The aquatic species comprise 68 marine algae, seven freshwater invertebrates, 38 corals, 30 sponges, 102 marine fish and eight freshwater fish. The terrestrial species comprise 40 higher plants, five amphibians, 28 reptiles, 166 birds (resident, endemic and migratory) and 18 mammals (DOF 2012). However, only one taxonomic list of rotifers, cladocera and copepods has been reported for Cozumel by Cervantes-Martínez et al. (2012), who reported 17 rotifer species from 12 sampling sites. For this reason, the present study adds to this list, by presenting an inventory of species richness and new records for the monogonot rotifers. 


\section{Materials and Methods}

In Cozumel, 51 biological samples from 17 freshwater systems were analysed. The aquatic system were cenotes, temporal and artificial ponds and mangrove ecosystems. Dissolve oxygen $(\mathrm{mg} / \mathrm{l})$, temperature $\left({ }^{\circ} \mathrm{C}\right)$ and electric conductivity $(\mu \mathrm{S} / \mathrm{cm})$, by means of a previously calibrated multi-parametric probe YSI Model 85, were measured in situ and for Max. Depth (m), we used a Secchi disc. Sampling was performed from 2014 to 2016, using a Wisconsin Plankton Net with a $45 \mu \mathrm{m}$ mesh. The collected material was preserved in alcohol and formaldehyde and live samples were also analysed in the laboratory. The organisms were identified by consulting specialised literature: Koste (1978), Nogrady et al. (1993), Shiel (1995), De Smet and Pourriot (1997), Sarma and Elías-Gutiérrez (1999), Segers (2007), Jersabek and Bolortsetseg (2010), Bertani et al. (2011). In some cases, it was necessary to isolate the trophi dissolving tissues using $\mathrm{NaOCl}$ and, after isolation, trophi were washed using distilled water; finally we preserved the trophi(?) semipermanently (Sarma and Elías-Gutiérrez 1997, Serranía-Soto 1996). Afterwards, the organisms were preserved permanently or semi-permanently, following techniques suggested by Nogrady et al. (1993). The organisms were photographed and illustrated using a camera connected to a high-resolution Zeiss Axio Imager A2 microscope and the AxioVision software SE64 Rel. 4.8. The new records for the state of Quintana Roo, Mexico were deposited in the Reference Collection of The College of the Southern Frontier (EI Colegio de la Frontera Sur) under the prefix ECO-CH-ZO. The other taxa were deposited by the authors in a zooplankton collection assigned to the CONACyT project number 2944.

\section{Results}

Four organisms were recorded in Cozumel and the state of Quintana Roo for the first time: Beauchampiella eudactylota, Mytilina bisulcata, Squatinella mutica and Dicranophorus epicharis. Overall, a total of 36 monogonot rotifers species were found (see Table 1), of which 25 had not been reported for Cozumel, increasing the known number of rotifers on the island from 17 to 40 species; the species belong to two orders, 11 families and 18 genera. Only two orders of Phylum Rotifera were encountered: Ploimida (11 families) and Flosculariaceae (one family). Lecane was the best represented genus, with 12 species, followed by the genus Brachionus, with four species. The aquatic system that registered the greatest quantity of species was the Maravillas cenote (19 species), followed by the Uvala and Torre cenote (11 species) and the Sin Barda cenote (nine species). Details of the physical and chemical parameters are shown in Table 2. All the aquatic systems studied are freshwaters: the average conductivity was $409.88 \mu \mathrm{S} / \mathrm{cm}^{3}$ and the average temperature was $26.81^{\circ} \mathrm{C}$. The depth was less than 2.27 metres. The dissolved oxygen average was $6.81 \mathrm{mg} / \mathrm{l}$. 
Table 1.

List of rotifers from Cozumel: monogonot rotifers had not been reported for Cozumel (*); new records for Quintana Roo $\left(^{+}\right)$; and new records for Mexico $\left({ }^{\circ}\right)$. The symbols " $X$ " and "-" indicate presence and absence of the species, respectively. Numbers correspond to the following sampling sites: 1 , Pileta UQROO; 2, Maravillas cenote; 3 , Sin Barda cenote; 4, Uvala cenote; 5 , Palmar cenote; 6, Observation Tower; 7, Caletita cenote; 8, Chenpita; 9, El Colombiano; 10, Chancanaab IV cenote; 11, Ositos cenote; 12, San Gervasio III; 13, Tres Potrillos cenote; 14, Garden cenote; 15, UQROO cenote; 16, Charco cancha UQROO; and 17, Echeverría cenote.

\begin{tabular}{|c|c|c|c|c|c|c|c|c|c|c|c|c|c|c|c|c|}
\hline \multirow{2}{*}{ Taxon } & \multicolumn{16}{|c|}{ Sampling Site } \\
\hline & 1 & 2 & 3 & 4 & 5 & 6 & 7 & 8 & 9 & 10 & 11 & 12 & 13 & 14 & 15 & 16 \\
\hline
\end{tabular}

SUBCLASS: MONOGONONTA

ORDER: PLOIMIDA

1. FAMILY: Brachionidae

Anuraeopsis fissa (Gosse, 1851)*

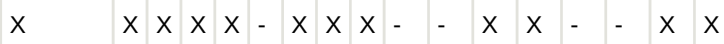

Plationus patulus (Müller, 1786)

Brachionus angularis Gosse, 1851*

Brachionus rubens Ehrenberg, 1838*

Brachionus plicatilis sensu lato*

Keratella americana Carlin, 1943

Platyias quadricornis Ehrenberg, 1832

2. FAMILY: Euchlanidae

Beuchampiella eudactylota (Gosse, 1886)

Euchlanis dilatata Ehrenberg, 1832*

3. FAMILY: Mytilidae

Mytilina bisulcata (Lucks, 1912) ${ }^{+}$

Mytilina ventralis (Ehrenberg, 1832)

Mytilina mucronata (Müller 1773)

\section{FAMILY: Colurellidae}

\begin{tabular}{|c|c|c|c|c|c|c|c|c|c|c|c|c|c|c|c|c|c|}
\hline Colurella adriatica Ehrenberg, 1831* & - & - & - & - & - & $x$ & $x$ & - & - & - & - & - & - & - & - & - & $\mathrm{x}$ \\
\hline Lepadella patella (Müller, 1773) & $x$ & $x$ & - & - & $x$ & - & - & - & - & - & - & $x$ & - & - & - & - & $x$ \\
\hline Lepadella ovalis (Müller, 1786)* & - & - & - & $x$ & - & - & - & - & $x$ & - & - & $x$ & - & - & - & - & $\mathrm{x}$ \\
\hline Lepadella rhomboides (Gosse, 1886)* & - & - & - & - & $x$ & - & - & - & - & - & - & $x$ & - & - & - & - & - \\
\hline Squatinella mutica (Ehrenberg, 1832) ${ }^{+}$ & - & $x$ & - & - & - & - & - & - & $x$ & - & - & - & - & - & - & - & - \\
\hline \multicolumn{18}{|l|}{ 5. FAMILY: Lecanidae } \\
\hline Lecane aculeata (Jakubski, 1912)* & - & - & - & $x$ & - & $x$ & - & - & - & - & - & - & - & - & - & - & - \\
\hline Lecane bulla (Gosse, 1851) & $x$ & $x$ & $x$ & $x$ & $x$ & $x$ & $x$ & $x$ & $x$ & $x$ & $x$ & - & - & - & - & $x$ & $\mathrm{x}$ \\
\hline Lecane closterocerca (Schmarda, 1859) & - & $x$ & $x$ & - & - & - & - & - & $x$ & - & - & - & - & - & - & $\mathrm{x}$ & - \\
\hline Lecane crepida Harring, 1914* & - & - & - & $x$ & - & $x$ & $x$ & - & - & $x$ & - & - & - & - & - & - & - \\
\hline
\end{tabular}




\begin{tabular}{|c|c|c|c|c|c|c|c|c|c|c|c|c|c|c|c|c|c|}
\hline \multirow[t]{2}{*}{ Taxon } & \multicolumn{17}{|c|}{ Sampling Site } \\
\hline & 1 & 2 & 3 & 4 & 5 & 6 & 7 & 8 & 9 & 10 & 11 & 12 & 13 & 14 & 15 & 16 & 17 \\
\hline Lecane cornuta (Müller, 1786)* & - & - & - & $x$ & - & - & - & - & $x$ & - & - & - & - & - & - & - & - \\
\hline Lecane elsa Hauer, 1931 & $x$ & $x$ & $x$ & $x$ & - & $x$ & - & - & - & $x$ & - & $x$ & - & - & - & $x$ & $x$ \\
\hline Lecane grandis (Murray, 1913)* & - & - & - & - & - & $x$ & - & - & - & - & - & - & - & - & - & - & - \\
\hline Lecane hamata (Stokes, 1896) & - & $x$ & $x$ & - & - & - & - & $x$ & - & $x$ & $x$ & - & - & - & - & - & - \\
\hline Lecane obtusa (Murray, 1913)* & - & - & - & - & - & - & - & - & - & $x$ & $x$ & - & - & - & - & - & - \\
\hline Lecane pyriformis (Daday, 1905)* & - & - & - & - & - & & - & - & - & $x$ & - & - & - & - & - & - & - \\
\hline Lecane quadridentata (Ehrenberg, 1830) & $x$ & $x$ & $x$ & $x$ & $x$ & $x$ & - & - & - & - & - & $x$ & - & - & $x$ & - & $x$ \\
\hline \multicolumn{18}{|l|}{ 6. FAMILY: Notommatidae } \\
\hline Cephalodella forficula (Ehrenberg, 1838)* & - & $x$ & - & - & - & - & - & - & $x$ & - & - & - & - & - & - & - & - \\
\hline Scaridium botsjani (Dames \& Dumont, 1974)* & - & - & - & - & - & - & - & - & - & $x$ & - & - & - & - & - & - & - \\
\hline \multicolumn{18}{|l|}{ 7. FAMILY: Trichocercidae } \\
\hline Trichocerca pusilla (Jennings, 1903) * & $x$ & $x$ & $x$ & - & - & - & - & - & - & - & - & - & - & - & - & - & - \\
\hline \multicolumn{18}{|l|}{ 8. FAMILY: Synchaetidae } \\
\hline Polyarthra cf. dolichoptera Idelson, 1925* & $x$ & $x$ & - & - & - & - & - & - & - & - & - & - & - & - & - & - & - \\
\hline Polyarthra vulgaris Carlin, 1943* & $x$ & $x$ & $x$ & - & - & - & - & - & $x$ & - & - & - & - & - & - & - & $x$ \\
\hline \multicolumn{18}{|l|}{ 9. FAMILY: Asplanchnidae } \\
\hline Asplanchnopus multiceps (Schrank, 1793) & - & - & - & - & - & - & - & - & - & - & - & - & $x$ & - & - & - & $x$ \\
\hline \multicolumn{18}{|l|}{ 10. FAMILY: Dicranophoridae } \\
\hline Dicranophorus epicharis Harring \& Myers, $1928^{+}$ & - & $x$ & - & - & - & - & - & - & $x$ & - & - & - & - & - & - & - & - \\
\hline \multicolumn{18}{|l|}{ ORDER: FLOSCULARIACEAE } \\
\hline \multicolumn{18}{|l|}{ 11. FAMILY: Testudinellidae } \\
\hline Testudinella patina (Hermann, 1783)* & - & - & $x$ & $x$ & - & $x$ & - & - & - & - & - & - & - & - & - & - & - \\
\hline
\end{tabular}

Table 2.

Geographical location and physical and chemical characteristics of the study sites. ND $=$ no data.

\begin{tabular}{|c|c|c|c|c|c|c|c|c|}
\hline No & Name of Site & Latitude N & Longitude W & $\begin{array}{l}\text { Type of } \\
\text { Sample }\end{array}$ & $\begin{array}{l}\text { Conductivity } \\
\left(\mu \mathrm{S} / \mathrm{cm}^{3}\right)\end{array}$ & $\begin{array}{l}\text { Dissolved } \\
\text { Oxygen } \\
\text { (mg/l) }\end{array}$ & $\begin{array}{l}\text { Max. } \\
\text { depth } \\
\text { (m) }\end{array}$ & $\begin{array}{l}\text { Temperature } \\
\left({ }^{\circ} \mathrm{C}\right)\end{array}$ \\
\hline 1 & $\begin{array}{l}\text { Pileta } \\
\text { UQROO }\end{array}$ & $20^{\circ} 29^{\prime} 17.9^{\prime \prime}$ & $86^{\circ} 56^{\prime 23.2 " ~}$ & Limnetic & 539.5 & 7.27 & 1.1 & 27.15 \\
\hline 2 & $\begin{array}{l}\text { Cenote } \\
\text { Maravillas }\end{array}$ & $20^{\circ} 29^{\prime} 28.1^{\prime \prime}$ & $86^{\circ} 56^{\prime} 50.2^{\prime \prime}$ & Limnetic & 230.35 & 14.31 & 1.2 & 21.35 \\
\hline 3 & $\begin{array}{l}\text { Cenote Sin } \\
\text { Barda }\end{array}$ & $20^{\circ} 29^{\prime} 11.2^{\prime \prime}$ & $86^{\circ} 57^{\prime} 19.9^{\prime \prime}$ & Limnetic & 500.1 & 1.91 & 2.1 & 28.4 \\
\hline 4 & Cenote Uvala & $20^{\circ} 22^{\prime} 8.0^{\prime \prime}$ & $86^{\circ} 58^{\prime} 7.6^{\prime \prime}$ & Littoral & 300.3 & 1.78 & $<1$ & 25.3 \\
\hline
\end{tabular}




\begin{tabular}{|c|c|c|c|c|c|c|c|c|}
\hline No & Name of Site & Latitude $\mathrm{N}$ & Longitude W & $\begin{array}{l}\text { Type of } \\
\text { Sample }\end{array}$ & $\begin{array}{l}\text { Conductivity } \\
\left(\mu \mathrm{S} / \mathrm{cm}^{3}\right)\end{array}$ & $\begin{array}{l}\text { Dissolved } \\
\text { Oxygen } \\
(\mathrm{mg} / \mathrm{l})\end{array}$ & $\begin{array}{l}\text { Max. } \\
\text { depth } \\
(\mathrm{m})\end{array}$ & $\begin{array}{l}\text { Temperature } \\
\left({ }^{\circ} \mathrm{C}\right)\end{array}$ \\
\hline 5 & $\begin{array}{l}\text { Cenote } \\
\text { Palmar }\end{array}$ & $20^{\circ} 21^{\prime} 59.8^{\prime \prime}$ & $86^{\circ} 58^{\prime} 19.2^{\prime \prime}$ & Littoral & 350.1 & 1.8 & $<1$ & 26.4 \\
\hline 6 & $\begin{array}{l}\text { Torre de } \\
\text { Observación }\end{array}$ & $20^{\circ} 32^{\prime} 31.2^{\prime \prime}$ & $86^{\circ} 52^{\prime} 47.5^{\prime \prime}$ & Limnetic & 767.9 & 12.45 & 2.1 & 25.8 \\
\hline 7 & $\begin{array}{l}\text { Cenote } \\
\text { Caletita }\end{array}$ & $20^{\circ} 29^{\prime} 42.1^{\prime \prime}$ & $86^{\circ} 57^{\prime} 47.6^{\prime \prime}$ & Littoral & 567.78 & 6.89 & 2.5 & 24.7 \\
\hline 8 & $\begin{array}{l}\text { Cenote } \\
\text { Chenpita }\end{array}$ & $20^{\circ} 22^{\prime} 59.8^{\prime \prime}$ & $86^{\circ} 58^{\prime} 5.0^{\prime \prime}$ & Limnetic & 458.6 & 19.5 & 5 & 29.1 \\
\hline 9 & $\begin{array}{l}\text { Cenote "El } \\
\text { colombiano" }\end{array}$ & $20^{\circ} 21^{\prime} 56.17^{\prime \prime}$ & $87^{\circ} 58^{\prime} 45.3^{\prime \prime}$ & Littoral & 210.5 & 5.6 & 2.3 & 30.5 \\
\hline 10 & $\begin{array}{l}\text { Chankanaab } \\
\text { IV }\end{array}$ & $20^{\circ} 26^{\prime} 31.67^{\prime \prime}$ & $86^{\circ} 59^{\prime} 40.14^{\prime \prime}$ & Littoral & 367.7 & 6.27 & 2.16 & 27.81 \\
\hline 11 & Charco Ositos & $20^{\circ} 29^{\prime} 28.62^{\prime \prime}$ & $86^{\circ} 56^{\prime} 24.55^{\prime \prime}$ & Littoral & N/D & N/D & N/D & N/D \\
\hline 12 & $\begin{array}{l}\text { San Gervasio } \\
\text { II }\end{array}$ & $20^{\circ} 26^{\prime} 32.49^{\prime \prime}$ & $86^{\circ} 51^{\prime} 43.51^{\prime \prime}$ & Littoral & 595.2 & 4.51 & 2 & 27.6 \\
\hline 13 & Tres Potrillos & $20^{\circ} 27^{\prime} 0.5^{\prime \prime}$ & $86^{\circ} 59^{\prime} 15^{\prime \prime}$ & Limnetic & N/D & N/D & 2.25 & 25.7 \\
\hline 14 & $\begin{array}{l}\text { Cenote } \\
\text { Gardner }\end{array}$ & $20^{\circ} 29^{\prime} 42.2^{\prime \prime}$ & $86^{\circ} 57^{\prime} 06.2^{\prime \prime}$ & Limnetic & $\mathrm{N} / \mathrm{D}$ & 2.01 & $<1$ & $\mathrm{~N} / \mathrm{D}$ \\
\hline 15 & $\begin{array}{l}\text { Cenote } \\
\text { UQROO }\end{array}$ & $20^{\circ} 29^{\prime} 19.22^{\prime \prime}$ & $86^{\circ} 56^{\prime} 26.36^{\prime \prime}$ & Limnetic & 230.35 & 6.87 & $<1$ & 27.15 \\
\hline 16 & $\begin{array}{l}\text { Cancha } \\
\text { UQROO }\end{array}$ & $20^{\circ} 29^{\prime} 15.80^{\prime \prime}$ & $86^{\circ} 56^{\prime} 30.33^{\prime \prime}$ & Littoral & N/D & 1.45 & $<1$ & 28.5 \\
\hline 17 & $\begin{array}{l}\text { Cenote } \\
\text { Echeverria }\end{array}$ & $20^{\circ} 29^{\prime} 14.95^{\prime \prime}$ & $86^{\circ} 57^{\prime} 11.28^{\prime \prime}$ & Littoral & 210.1 & 9.63 & $<1$ & N/D \\
\hline
\end{tabular}

New records of species that were found are described below.

Brachionus rubens (Fig. 1). Measured length of $176.55 \mu \mathrm{m}$. Anterolateral margin with six spines. Middle spines are longer and sharper than intermediate spines, which are wider at the base. Undulate anterodorsal margin with two striae on each side; elevated central portion with a U-shaped groove. Foot opening with a square aperture; rounded prolongation towards the central body. $B$. rubens is an epizoic rotifer, although it was not observed in association with other species. Even so, B. rubens may be associated with insect larvae and cladocera in Cozumel, as observed in other areas.

Brachionus plicatilis s.I (Fig. 1). This species belongs to the B. plicatilis species complex, wich actually comprises 15 species (Mills et al. 2017) divided into three sizes. The $B$. plicatilis s.l measured $103.21 \mu \mathrm{m}$ in length, placing it within the smaller-sized $B$. rotundiformis forms category. Spines end in sharp points, protruding from the body in a $\mathrm{V}$ shape. García-Morales and Elías-Gutiérrez (2013) reported the DNA sequences of samples of the $B$. plicatilis species complex collected in south-eastern Mexico. However, a 
detailed analysis of the clonal population structure of the species complex from the Yucatan Peninsula is required.

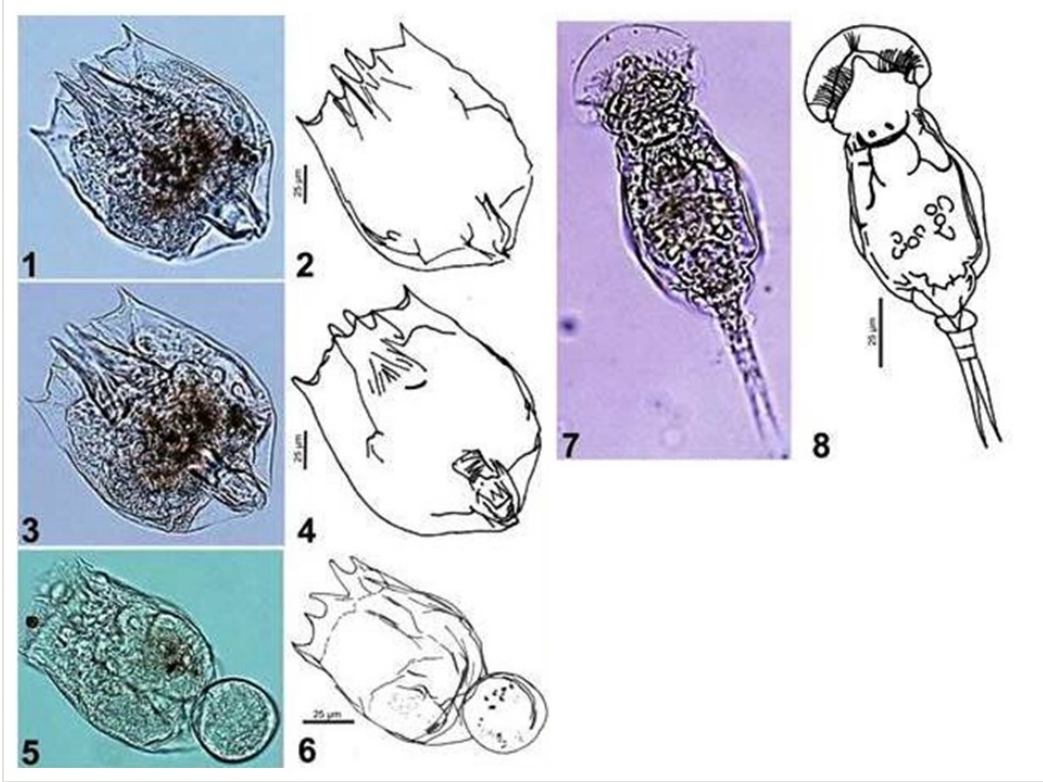

Figure 1. doi

Rotifers of cozumel, 1-4) Brachionus rubens; 5, 6) Brachionus plicatilis s.l.; 7, and 8) Squatinella mutica.

Squatinella mutica (Fig. 1). Ovoid body approximately $110 \mu \mathrm{m}$ in length; head and ciliary corona located beneath a well-developed semicircular hyaline sheath with an opening of $134 \mu \mathrm{m}$. Smooth dorsal and ventral lorica. Posterior portion of body is rounded. Foot formed by two segments with two long toes, each $27 \mu \mathrm{m}$ in length that end in sharp points without claws or pseudoclaws. Few records exist for this species; in general, its behaviour is not well known.

\section{Discussion}

The number of rotifer species reported in Cozumel has increased to a total of 40, grouped into two orders, 11 families and 18 genera. Segers (1995) mentioned that 380 taxa of the genus Lecane have been described worldwide; its preference for littoral aquatic environments and its adaptive capacity enables the wide distribution of this genus compared with other groups. In Mexico, 57 rotifer species have been reported (CervantesMartínez et al. 2012) and 46 of these species have been recorded in the south-western region of the country: Quintana Roo, Tabasco, Chiapas and Campeche (Quiroz-Vázquez 2012). Notably, island ecosystems are fragments of natural habitats where species and communities have been separated from the continent and have established, adapted and 
evolved in a unique manner. For this reason, these environments are critically important for global biodiversity (Lara-Lara et al. 2008).

For example, the rotifer fauna of tropical and Caribbean islands mostly reflect the fauna of the closest continental region (Janetzky et al. 1995). Suárez-Morales and Reid (2003) also supported this idea and suggested that the zooplankton species that inhabit the Yucatan, especially in Quintana Roo, are the result of the geological history of the region. Geologically, Cozumel is considered part of the plate that forms the Yucatan Peninsula (Pacheco and Vega 2008) and shares certain features with this region, such as karstic subsoil and high soil permeability, which facilitate the formation of subterranean caves, cenotes and sinkholes (Lesser et al. 1978). Of the 42 species registered in Cozumel, 35 taxa have previously been reported in the continental region of Quintana Roo, including Keratella americana, Lecane bulla, L. crepida, L. hastata and L. lunaris, which are considered common in this state. In fact, a large portion of these species are considered cosmopolitan (Elías-Gutiérrez and García-Morales 2011).

The genera Lecane and Brachionus were the most common taxa represented in this study; this observation agrees with studies performed by García-Morales and Elías-Gutiérrez (2004), Zanatta et al. (2007), García-Morales and Elías-Gutiérrez (2007) in the southeastern region of Mexico. In fact, these genera are often dominant in the freshwater systems of tropical belts (Keppeler and Hardy 2004). Additionally, environmental factors such as latitude, temperature and conductivity had an effect on species richness of Brachionidae and Lecanidae; for example, latitude had an effect only on species composition of Lecanidae (Sa-ardrit et al. 2017).

The rotifer species identified in this study are largely typical of littoral habitats. This observation may be attributed to the nature of freshwater systems in Cozumel, which are predominantly shallow $(<2 \mathrm{~m}$ ) and small (18 $\mathrm{m}$ in diameter) (Gutiérrez-Aguirre and Cervantes-Martínez 2008), in comparison with the continental aquatic system of the Yucatan Peninsula (47 $\mathrm{m}$ in depth and $280 \mathrm{~m}$ in diameter) (Cervantes-Martínez et al. 2009). The species diversity of rotifers in Quintana Roo corresponds with the physical and chemical characteristics of its aquatic systems (Elías-Gutiérrez and García-Morales 2011). In general terms, its water bodies are oligotrophic, warm tropical and well oxygenated and have good visibility (Cervantes-Martínez 2005), which differ notably from the mesoeutrophic systems, common throughout the rest of Mexico.

MacArthur and Wilson (1967) mention that, for islands, species richness is directly related to island size and distance from the closest continent. Segers and Dumont (1993) also elaborate this point and affirm that the species richness of islands is related to the distance to the closest continent and territorial extension. For example, Janetzky et al. (1995) registered a total of 177 rotifer species in 60 aquatic systems in Jamaica, an island with an area of approximately $10,991 \mathrm{~km}^{2}$ located $630 \mathrm{~km}$ from the South American continent. This richness may be attributable to the island's proximity and size.

As previously mentioned, the proximity of Cozumel to the continental coast and its territorial extension could be factors that positively influence its rotifer richness. This idea is 
in agreement with Yáñez-Mendoza (2008), who studied rotifers in 250 natural pools on the island; approximately 41 pools were major aquatic systems (depths $>3 \mathrm{~m}$ ). In this study, only 17 sampling sites of lesser depths $(>2 \mathrm{~m}$ ) were evaluated. As the study of the zooplankton fauna of Cozumel intensifies, the number of monogonot rotifer records for island aquatic environments is likely to increase.

The greatest numbers of species registered in island systems are found in the Neotropical and Eastern biogeographic territories, followed by the Palearctic territory; the lowest number of species is found in the Nearctic territory. Australasia is the most studied island system, in which 687 rotifer species have been recorded. The same study reported 133 rotifer species in the islands of the Pacific Ocean (Segers 2008). Finally, we recommend that additional taxonomic studies be carried out on the zooplankton of Mexican island systems since presumably only a small proportion of the existing taxonomic forms are known (Alonso 1984). Perhaps the potential endemism of island plankton species as a result of the unique characteristics of island environments could also be highlighted (Brown and Lomolino 1998, Lomolino and Weiser 2001).

\section{Acknowledgements}

The authors thank the Ejido Villa Cozumel for the support in the exploration of two sites on the island. We also thank Alma Estrella Garcia-Morales for her comments.

\section{Funding program}

CONACyT, Project number 2944.

\section{Grant title}

Modelling the water cycle of the Yucatan Peninsula: biodiversity of zooplankton from the karst systems.

\section{Hosting institution}

Centro de Investigación Científica de Yucatán A.C

\section{Ethics and security}

All applicable international, national and/or institutional guidelines for the care and use of animals were followed by the authors. 


\section{Author contributions}

All authors contributed equally to samples collection and processing and the writing of the manuscript.

\section{Conflicts of interest}

The authors declare that they have no conflict of interest.

\section{References}

- $\quad$ Aguirre-Muñoz A, Bezaury-Creel JE, De la Cueva H, March-Mifsut IJ, Peters-Recagno E, Rojas-González de Castilla S, Santos-del Prado Gasca K (2010) Islas de México. Un recurso estratégico. Islas de México. Un recurso estratégico. Instituto Nacional de Ecología (INE), The Nature Conservancy (TNC), Grupo de Ecología y Conservación de Islas, A.C. (GECl), Centro de Investigación Científica y de Educación Superior de Ensenada (CICESE), Mexico, 50 pp.

- $\quad$ Alonso M (1984) Crustáceos y rotíferos de la laguna del tesoro (Cuba). Limnética 1: 70-77.

- Benítez-Díaz MI, Castellanos-Páez ME, Garza-Muriño G, Ferrara-Guerrero MJ, Pagano M (2014) Spatiotemporal variations of zooplankton community in a shallow tropical brackish lagoon. Zoological Studies 53: 59. https://doi.org/10.1186/s40555-014-0059-6

- Bertani I, Segers H, Rossetti G (2011) Biodiversity down by the flow: new records of monogonont rotifers for Italy found in the Po River. Journal of Limnology 70 (2): 321-328. https://doi.org/10.3274/JL11-70-2-N3

- $\quad$ Brown JH, Lomolino MV (1998) Biogeography. Geology Magazine 136 (4): 475-478.

- Cervantes-Martínez A (2005) Análisis limnólogicos de dos sistemas cársticos (cenotes) de la Península de Yucatán con énfasis en la variación espacial y temporal del zooplancton. PhD Thesis. El Colegio de la Frontera Sur, Chetumal, Quintana Roo, México, 171 pp.

- Cervantes-Martínez A, Mazeta-Barrerra M, Gutiérrez-Aguirre M (2009) Limnología básica del lago cárstico turístico Cenote Azul en Quintana Roo, México. Hidrobiológica 19 (2): 177-180. URL: http://hidrobiologica.izt.uam.mx/index.php/revHidro/article/view/839/429

- $\quad$ Cervantes-Martínez A, Gutiérrez-Aguirre MA, Delgado-Blas V, Ruíz-Ramírez J (2012) Especies de zooplancton dulceacuícola de Cozumel. Universidad de Quintana Roo. México, D.F. 58 pp.

- CONABIO-CONANP-TNC-PRONATURA (2007) Análisis de vacíos y omisiones en conservación de la biodiversidad marina de México: océanos, costas e islas. Comisión Nacional para el Conocimiento y Uso de la Biodiversidad, Comisión Nacional de Áreas Naturales Protegidas, The Nature Conservancy, Programa México. Pronatura, A.C. México, D.F. URL: https://www.biodiversidad.gob.mx/pais/pdf/LibroGapMarino.pdf

- De Smet WH, Pourriot R (1997) Rotifera: The Dicranophoridae and the Ituridae (Monogononta). Guides to the identification of microinvertebrates of the continental waters of the world. Vol. 5: 478 pp. https://doi.org/10.1002/iroh.19970820405

- DOF (2012) DECRETO por el que se declara área natural protegida, con el carácter de Área de protección de flora y fauna, la porción norte y la franja costera oriental, terrestres y 
marinas de la Isla de Cozumel. Municipio de Cozumel, Estado de Quintana Roo. Quintana Roo, Cozumel.

- $\quad$ Elías-Gutiérrez M, García-Morales A (2011) Un análisis para su conservación. In: Pozo C (Ed.) Riqueza biológica de Quintana Roo. 2. El Colegio de la Frontera Sur (ECOSUR), Comisión Nacional para el Conocimiento y Uso de la Biodiversidad (Conabio), Gobierno del Estado de Quintana Roo y Programa de pequeñas aportaciones (PPD), Chetumal, 103 pp.

- García-Morales A, Elías-Gutiérrez M (2004) Rotifera from southeastern Mexico, new records and comments on zoogeography. Series Zoology 75: 99-120. URL: http:// www.ejournal.unam.mx/zoo/75-01/ZOO75103.pdf

- García-Morales A, Elías-Gutiérrez M (2007) The Rotifer fauna of Guatemala and Belize: survey and biogeographic affinities. Revista de Biología Tropical 55: 569-584. URL: http:// www.scielo.sa.cr/scielo.php?script=sci arttext\&pid=S0034-77442007000200018

- García-Morales A, Elías-Gutiérrez M (2013) DNA barcoding of freshwater rotifera in Mexico: evidence of cryptic speciation in common rotifers. Molecular Ecology Resource 13 (6): 1097-1107. https://doi.org/10.1111/1755-0998.12080

- $\quad$ Gutiérrez-Aguirre M, Cervantes-Martínez A (2008) Cladóceros y copépodos dulceacuícolas. Mejía-Ortiz LM (Ed..). Biodiversidad acuática de la Isla de Cozumel. Universidad de Quintana Roo y Valdez, Cozumel, 149 pp.

- Janetzky W, Koste W, Vareschi E (1995) Rotifers of Jamaica inland water a synopsis. Ecotropica 1: 31-40.

- Jersabek C, Bolortsetseg E (2010) Mongolian rotifers (Rotifera, Monogononta) a checklist with annotations on global distribution and autecology. The Academy of Natural Sciences of Philadelphia 159: 119-168. https://doi.org/10.1635/053.159.0108

- $\quad$ Keppeler EC, Hardy ER (2004) Abundance and composition of rotifera in an abandoned meander lake (Lago Amapá) in Rio Branco, Acre, Brazil. Revista Brasileira de Zoología 21 (2): 233-241. https://doi.org/10.1590/S0101-81752004000200011

- $\quad$ Koste W (1978) Rotatoria. Die Radertiere Mitteleuropas, Borjtraeger, Berlin, 673 pp.

- Lara-Lara JR, Arreola-Lizárraga JA, Calderón-Aguilera LE, Camacho-lbar VF, De la LanzaEspino G, Escofet-Giansone A, Espejel Carbajal MI, Guzmán-Arroyo M, Ladah LB, Hernández ML, Meling-López EA, Casasola-Barceló PM, Reyes-Bonilla H, Ríos-Jara E, Zertuche-González JA (2008) Los ecosistemas costeros, insulares y epicontinentales. In: Sarukhán J (Ed.) Capital Natural de México. 1. CONABIO, México, 134 pp. URL: https:// www.biodiversidad.gob.mx/pais/pdf/CapNatMex/Vol\%20l/I04_Losecosistemascos.pdf

- $\quad$ Lesser H, Azpeitai J, Lesser JM (1978) Geohidrología de la Isla de Cozumel, Q. Roo. Recursos Hidráulicos 7 (1): 32-50.

- Lomolino M, Weiser M (2001) Towards a more general species area relationship: diversity on all islands, great and small. Journal of Biogeography 28: 431-445. https:// doi.org/10.1046/j.1365-2699.2001.00550.x

- MacArthur R, Wilson E (1967) The theory of island biogeography. Princeton University Press, 203 pp.

- Mills S, Alcántara-Rodríguez JA, Ciros-Pérez J, Gómez A, Hagiwara A, Hinson-Galindo K, Jersabek CD, Malekzadeh-Viayeh R, Leasi F, Lee JS, Mark-Welch DB, Papakostas S, Riss S, Hendrix S, Serra M, Shiel R, Smolak R, Snell TW, Stelzer CP, Tang CQ, Wallace RL, Fontaneto D, Walsh EJ (2017) Fifteen species in one: deciphering the Brachionus plicatilis species complex (Rotifera, Monogononta) through DNA taxonomy. Hydrobiologia 796:

39-58. https://doi.org/10.1007/s10750-016-2725-7 
- $\quad$ Nogrady TR, Wallace L, Snell TW (1993) Rotifera. Biology, Ecology and systematics. Guides to the identification of the microinvertebrates of the continental waters of the World. Vol. 4. SPB Academia Publishing, Netherlands, 142 pp.

- $\quad$ Pacheco M, Vega F (2008) Reseña geológica. In: Mejía-Ortíz L (Ed.) Biodiversidad acuática de la Isla de Cozumel. Universidad de Quintana Roo-Plaza y Valdés, Cozumel, Q. Roo, México, 33-42 pp.

- Quiroz-Vázquez P (2012) Base de datos de la colección de zooplancton de agua dulce de ECOSUR, Chetumal. Informe final SNIB- CONABIO proyecto No. HC001-20 URL: https:// www.gbif.org/dataset/a7ac0110-c78f-42df-8c12-bc13492ad03a

- $\quad$ Rico-Martínez R, Silva-Briano M (1993) Contribution to the knowledge of the rotifera of Mexico. Hydrobiología 255 (256): 467-474. https://doi.org/10.1007/BF00025875

- Sa-ardrit P, Pholpunthin P, Segers H, Fontaneto D (2017) The influence of environmental variables on freshwater rotifers of the family Brachionidae and Lecanidae in Thailand. Tropical Zoology 30: 28-48. https://doi.org/10.1080/03946975.2017.1278664

- $\quad$ Salazar-Vallejo SI, González NE (1993) Panorama y fundamentos para un programa nacional. In: Salazar-Vallejo S, González N (Eds) Biodiversidad marina y costera de México. CONABIO/CIQRO, México.

- Sarma S, Elías-Gutiérrez M (1999) A survey on the rotíferan (Rotifera) fauna of the Yucatán Península (México). Revista de Biologia Tropical 47: 187-196. URL: https:// revistas.ucr.ac.cr/index.php/rbt/article/view/26196/26449

- $\quad$ Sarma SSS, Elías-Gutiérrez M, Serranía-Soto C (1996) Rotifers from high altitude Crater Lake at Nevado de Toluca volcano, Mexico. Hidrobiológica 6: 33-38. URL:

http://148.206.53.234/revistasuam/hidrobiologica/include/getdoc.php? id $=129 \&$ article $=157 \&$ mode $=$ pdf

- $\quad$ Sarma SSS, Elías-Gutiérrez M (1997) Taxonomic studies of fresh water rotifers (Rotifera) from Mexico. Polskie Archiwum Hydrobiologii 44: 341-357.

- $\quad$ Sarma SSS, Elías-Gutiérrez M (1998) Rotifer diversity in a central Mexican pond. Hydrobiologia 387 (388): 47-54. https://doi.org/10.1023/A:1017008918839

- $\quad$ Sarma SSS, Nandini S, Ramírez-García P, Cortés-Muñoz JE (2000) New records of brackish water Rotifera and Cladocera from Mexico. Hidrobiologica 10 (2): 121-124. URL: http://hidrobiologica.izt.uam.mx/index.php/revHidro/article/view/911

- $\quad$ Schmitter-Soto J, Comín E, Escobar-Briones J, Herrera-Silveira J, Alcocer E, SuárezMorales H, Elías-Gutiérrez M, Díaz-Arce V, Marín L, Steinich B (2002) Hydrogeochemical and biological characteristics of cenotes in Yucatan Peninsula (SE Mexico). Hydrobiologia 467: 215-228. https://doi.org/10.1023/A:1014923217206

- Segers H, Dumont HJ (1993) Zoogeography of Pacific Ocean islands: a comparison of the rotifer faunas of Easter Island and the Galapagos Archipelago. Hydrobiologia 255 (256): 475-480. https://doi.org/10.1007/BF00025876

- $\quad$ Segers H (1995) World records of Lecanidae (Rotifera, Monogononta). Editiom de Institut royal des Sciences naturelles de Belgique, 118 pp. URL: https://core.ac.uk/download/ pdf/35105772.pdf

- $\quad$ Segers H (2007) Annotated checklist of the rotifers (Phylum Rotifera), with notes on nomenclature, taxonomy and distribution. Zootaxa 1564: 1-104. https://doi.org/10.11646/ zootaxa.1564.1.1

- $\quad$ Segers H (2008) Global diversity of rotifers (Rotifera) in freshwater. Hydrobiologia 595: 49-59. https://doi.org/10.1007/s10750-007-9003-7 
- Serranía-Soto C (1996) Diversidad de Rotíferos Monogonontos en algunos sistemas acuáticos del Estado de México. Universidad Nacional Autónoma de México, Los Reyes, Iztacala, Estado de México, 74 pp.

- $\quad$ Shiel RJ (1995) A guide to identification of rotifers, cladocerans and copepods from Australian inland water. Co-operative Research Center for Freshwater ecology, Australia, 144 pp. URL: https://catalogue.nla.gov.au/Record/1763551 [ISBN 0646224107]

- Suárez-Morales E, Reid JW (2003) An updated checklist of the continental copepod fauna of the Yucatan Peninsula, Mexico, with notes on its regional associations. Crustaceana 78 (8): 977-991. https://doi.org/10.1163/156854003771997855

- Yáñez-Mendoza G (2008) Sistemas anquihalinos. In: Mejía-Ortiz L (Ed.) Biodiversidad acuática de la isla de Cozumel. Universidad de Quintana Roo, Plaza y Valdés, Cozumel, Q. Roo, México, 49-61 pp.

- Zanatta S, Torres-Orozco B, Zavala-Hurtado J, Pérez-Hernández M (2007) Plankton rotifers from a tropical lake: differences in distribution and migration patterns in two mixing events, with similar abiotic conditions. Hidrobiológica 17: 1-10. URL: http:// hidrobiologica.izt.uam.mx/index.php/revHidro/article/view/947 